\title{
BANKING PRODUCT AND SERVICES DEVELOPMENT PROJECTS: THE WAY TO IMPLEMENT INNOVATIONS
}

\author{
Ivana Simonović ${ }^{1}$, Marija Todorović ${ }^{2}$ \\ ${ }^{I} N L B$ bank, Belgrade, Serbia \\ ${ }^{2}$ Faculty of Organisational Sciences, University of Belgrade, Serbia
}

\begin{abstract}
Changes in the banking sector business are increasing, technological processes are developing, new ideas are being created, innovation processes are being encouraged and new technologies are being implemented. Banking products are becoming more and more important to the citizens allowing customers to have 24/7 banking services without going to the bank. Consequently, products and services development is crucial to bank's business values, strategic positioning and profit. Project-based management has become increasingly important in the banking sector in the last decade. This paper aims to present project management as an adequate tool by which many innovative ideas can be brought to the life. The idea of a new product can be realized through the five stages of the project life cycle. The paper highlights the need for new products and services development and demonstrates the application of project management in the banking products and services development process, stressing out project management elements that are most relevant to the banking sector.
\end{abstract}

Key words: bank innovative products and services, project management.

\section{BANKING SECTOR}

The first modern banks were established in Italy: the Banca di Genova founded in 1320 and the Casa di Sant Georgio founded in 1407. The primary goal of banking is to maximize profits and increase equity.

Today, banking is highly developed and offers a large number of products and services to its customers. Banking is evolving rapidly, so new products are gaining ground. Modern banking products are becoming more and more significant for the population; the goal is to shorten the operating time of the branches and to enable clients to have 24/7 opportunities to use banking services without going to the bank. New banking products are increasingly used by new generations. That is why banks should aim to inform their clients as much as possible about new products and the importance of using them, pay attention to them and train them to use innovative products (Sanader, 2014; Lučić, 2007).

When creating an idea, it is necessary to look at new opportunities and find where there is a gap in the market, whether there is a possibility to change the way of doing business, to introduce a new product or services or to introduce new technology that will contribute to facilitating and developing the process.

Banks are interested in increasing customer service that can always be available to customers while generating profit for the bank requires investment costs. Thus, the latest innovations include payment by mobile phones, ATMs that use mobile phones instead of payment cards, digital wallet, voice marketing and others.

\subsection{Innovative projects in the banking sector}

The market is continually changing, technological processes are developing, new ideas are being created, innovation processes are becoming more frequent in the banking and financial world. To maintain their market position, banks must continuously work to improve their operations. This can be achieved through continuous market research, customer needs for specific products and services, improvements of existing and new product development, innovations and care

Corresponding author. Email: marija.todorovic@ fon.bg.ac.rs

ISSN 2560-4961 (online)

(C) 2019 IPMA Serbia

doi: 10.18485/epmj.2019.9.1.1 
for employees who work to support the overall process (Trott, 2005). Further, public relations work and the study of Customer Relationship Management (CRM) are very important.

In the banking sector, project-based management has become increasingly important in the last decade. Projects are recognized as a very effective means by which many processes can be executed in a much more orderly manner (Knežević, Todorović, \& Obradović). The typical project for the banking sector are:

- Operational projects are small projects that aim to effectively implement processes that are continuously implemented in banks and are customer-focused. The projects are generally carried out with routine and are internal that is, e.g. solving problems that arise in information systems, technological upgrades, continuous training of employees, etc.

- Growth-oriented projects are strategic projects that the bank wants to increase its market share, increase profits, etc. new product development, diversification projects, projects to increase market share, etc. These projects aim to increase customer satisfaction, also increase market share and secure market position.

- Development-oriented projects are also presented as strategic projects that do not immediately yield measurable financial results but give other positive effects significant for the bank's operations, e.g. development of information and communication technologies, reorganization of the system, etc. These projects are also internal efficiency-oriented projects.

- Emergency projects arise as a need after events that influence normal banking operations and need to be resolved as soon as possible, with the highest priority, regardless of other projects,e.g. solving problems arising from incidents that deregulate the normal operation of the bank.
In line with recent trends, banks are massively introducing ATM machines. ATMs are of great importance to the banks because they reduce the crowds at the branches, while clients can receive services as at the bank. That is why banks decide to set up their ATMs and in places where they do not have an open branch, such as shopping malls, office buildings, train stations, airports, etc. Banks also want to introduce a new ATM that is an innovation for our premises and the market (Banfield \& Ericsson, 2017). These are ATMs where we can withdraw money without using a card, but with the help of mobile phones. It is enough for the client to have a "smart" phone and can connect to this device using NFC (Near Field Communication or Short Field Communication), QR (Quick Response or two-dimensional bar codes), biometrics (fingerprint recognition or eye pupil identification). The fact is that by $2020,75 \%$ of the population will use smartphones. That is why it wants to slowly introduce this innovative product and give customers the opportunity to learn about the way banks work and the opportunity to get the money they need faster, safer and better.

\subsection{Project management in the banking sector}

Project management in banks is differently conceptualized than in other companies. Some specific characteristics for project management in the banking sector, include the following (Vrečko, Barilović, \& Božičev, 2015):

- The organizational structure defined by the regulatory bodies is very significant

- The processes within and outside the department are continuous and harmonized, and also interdependent that require the high level of organization in order to achieve results without major delays.

- Banks offer their services 24/7 a week throughout the year, so any delay in introducing a new product or new software is measured in the shortest time units because the time for banking is very important for its business success

- Risk is very present in the banking business if any unforeseen system shutdown can result ina negative perception of banking service by customers. 
- Projects related to intervention and regulation appear relatively frequently and present a priority over other banking projects. This is why banking portfolio management faces a great challenge when allocating resources to projects

- Data security is very important, that is why any data transaction is monitored and protected; also few people have access to important data

Projects that enable growth and development are significant for banks since they support successful operations (Knežević et al.). However, statistics indicate a small percentage of the successfully finished banking projects - only 39\% of projects successfully completed, $43 \%$ complete with certain complications, and $18 \%$ of projects not completed.

\section{PROJECT PHASES IN NEW PRODUCT AND SERVICES DEVELOPMENT}

Product development projects contribute to the faster and easier implementation of new product introduction phases, with the help of projects, the idea on paper can be realized and a new product created through the five stages of the project life cycle. As with all projects, product and service development projects in the banking sector should go through five phases of the project lifecycle: initiation, planning, execution, control and monitoring of implementation and project closure. The phases of the project life cycle will be discussed below.

\subsection{Project initiation}

To initiate a new product development project in banks, the following phases are necessary:

- Define all project stakeholders: project manager, project team, the environment in which the project is being implemented, consider the competition offer, client needs and see what other stakeholders can have an impact on the project - its ultimate goal, product/service.

- It is necessary to carefully define the project scope, costs and benefits that may arise on the project

- The feasibility of a project (feasibility study)
- It is necessary to measure performance to understand which set of goals can be achieved and how we can measure it.

At the project initiation stage a business case should be prepared to approve the business value: detailing the opportunities to be exploited or the problem to be solved, solutions suggested, then benefits and costs incurred in solving the problem, or using the opportunity, and finally an optimal solution selection (Banfield, \& Ericsson, 2017).

For each new product development projects bank starts from the client's needs analysis. The most responsible for this are the branches. The bank can also see on the basis of monthly reports which products bring the most profit, then which products are the most profitable and what is something that can be improved to increase the number of interested users (Đorđević, 2006). For example, Sberbank has created a credit card called Super Card, which is both a payment and a loyalty card, which means that with it the user can conduct financial transaction both at home and abroad and collect points with Super Club members in the country. This credit card was a very profitable project for the bank and brought a lot of new customers.

Project management considers the following options during product development (Trott, 2005):

- New product but similar to an existing product (e.g. a credit card that has the function of loyalty cards in addition to payment).

- Modernization of existing products (e.g. vending machines that can be used to exchange bills).

- Special enhancements to existing products (e.g. changes to the design of a credit card or additional services that come with opening a current account).

- Completely new products (e.g. payments by mobile phone)

The product development platform that the product development department will choose depends on the banking policy, the budget that the bank will dedicate for the development of the new product, and the business goals the bank wants to achieve by developing the new product (Banfield \& Ericsson, 2017). 
Each bank has already formed a project team working on the creation of a new product. The team works most closely with Sales, IT, R\&D and Marketing. They work with them to create an idea and receive guidance on how to carry out the project to the end with the expected results.

Bank also choose different business partners who will supply them with the necessary materials and devices that are necessary for new products to exist and function. For example, companies that make plastic for debit and credit cards, IT companies for application development, etc.

At this stage, a project marketing has very important role, aiming to improve communication on the project, reduce conflicts, to assist project managers in selecting the right personnel to implement the project, to provide sufficient management attention to the project (Gareis, 2005).

Project managers must define well the stakeholders, their influence and interests since they can highly impact the success or failure of the project.

Beside stakeholders analysis, financial analysis is required at the project initiation stage. Financial analysis includes the analysis of ratio numbers, analysis of financial, total and business risk, analysis of financial flows. Ratio analysis uses indicators of liquidity, profitability, profitability, financial structure, market value (Gareis, 2005).

The financial analysis also includes risk analysis:

- business risk is the calculation of the percentage of operating profit relative to the percentage change in sales volume.

- Financial risk is the percentage ratio of operating profit to profit before tax.

- Total risk is the measurement of corporate risk exposure based on a combination of business and financial risk.

In order to evaluate the justification of a project before its implementation, it is necessary to make a preliminary analysis of the costs that will occur during its realization and the profits that the project will bring to the bank after its realization. Financial cost analysis includes the following reports:

- Report on flows of total operating assets

- Report on flows of net current assets

- Cash Flow Statement.

\subsection{Project planning}

The project management plan should include how the project team selects processes ant activities, how the work will be carried out to achieve the project goals, should define how the project will be coordinated, monitored and controlled, how the stakeholder communication will, how changes will be monitored, and problem detected, etc. (Lock, 2007).

In practice, the purpose of the project management plan is to define how project activities will be coordinated project and how the team will control their execution. The plan must also indicate which reports will be used in order to see the progress of the project and anticipate possible problems so that adequate responses can be prepared in a timely manner to prevent or reduce their impact.

During planning a product development project in the banking sector, different information is used from $\mathrm{R} \& \mathrm{D}$, marketing and competition analysis (Vrečko et al., 2015).

Project schedule, cost plan (planned and not planned) as well as a resource plan need to be defined. When planning a new product or service development project in the banking sector, it is not always necessary to hire new resources, and the bank to have a permanent team working on projects and collaborating with other departments. Sometimes, it may take several months for individual resources from other departments, such as IT, to deal solely with the realization of a thoughtful project. These are often larger projects involving more people.

When engaging resources, their availability must be taken into account, as there may be situations where more people are engaged for certain activities, while others lack resources. For this reason, the resources levelling is made by shifting the execution of certain activities that will cause the least cost. This 
extends the duration of the project but does not significantly increase the cost of projects. On projects in banking sector, the main cost is the cost of equipment, appliances and installations, and delivery delays (Gareis, 2005). For this reason, it is necessary to make a choice among more available equipment providers, taking into account the contracting time around the equipment.

\subsection{Project execution}

Project implementation involves the execution of activities by project managers and project team that are defined with the project's scope. Planned activities need to be carried out in order to achieve the project's goals, the project team needs to be trained and well informed for the implementation of activities, the necessary resource, and materials should be obtained. Further, planning and control methods now should be performed, and focus should be on managing communication channels and managing risk and risk responses. The input for the realization phase is the project management plan, while the outputs are (Barkley, 2018):

- Delivery of the product that has been verified, the result or the ability to perform the service identified in the project management documentation

- Implemented change requests by the project team responsible for the implementation of the project

- Corrective actions implemented by the project team

- Preventive measures implemented to reduce project risks

- Collected information about work performed.

Communication management and project team management are key activities during project implementation. The project manager is, in the case of the bank, the product management director. He/she needs to coordinate the activities of all project participants, get information from a team leader who directly oversees project implementation and reports to the senior manager on project progress (Lichtarski, 2018). The project manager needs to have good communication skills to be able to communicate with that leader, team and his/her superiors who require feedback from the project realization (Todorović, \& Obradović, 2018).

However, in addition to standard activities, particular attention should be paid to project changes that may be caused by internal and/or external projects and are quite common in this industry. Changes in the financial market, so they need to be monitored by market research. Banks are constantly looking for new opportunities to improve their business by constantly investing in new products. Nowadays, innovations are increasing, and customers are offered options that make it easy to pay without going to the bank and paying with cash. The role of cards is slowly taken over by mobile phones with which clients can pay their dues. Also, lately, payment for the public transport with payment cards has been popular, without buying a ticket at the points of sale or at the bus driver.

Product development managers have to constantly analyze markets and notice changes and be aware of digital era requirements (Obradović, Montenegro, \& Bjelica, 2018), only in this way they can keep up with the competition. They must have developed an atmosphere-creating skill that will support change and encourage it. When planning changes, it is then necessary to look at the project and determine what changes have occurred. Identify any negative impacts and problems they cause. Define adequate responses to changes accordingly.

The success of introducing change depends on the skill, ability and knowledge of the project manager who is introducing the change. $\mathrm{He} / \mathrm{she}$ needs to know how to overcome people's resistance, to embrace change, formulate a change-making strategy, and hire a professional consulting team to help implement change (Toljaga-Nikolić, Obradović, \& Mihić, 2011). Once the changes are implemented, it is necessary to determine whether the changes have succeeded in solving the problem that led them to this process.

Banks specifically manage project risk. Risk management does not imply the existence of a separate organizational unit, but risk management is implemented in each organizational unit that implements the 
project. Each sector is engaged to risk management for its part of the business, identifying and analyzing possible risks and risk reaction.

Management is focused on preventing risk, as certain risks can bring damage that can cause higher costs than planned (Kerzner, 2009).

\subsection{Project monitoring and control}

Gathering information, measuring results are very important processes of monitoring and control for finding difficulties and problems that could disrupt the normal project implementation.

What needs to be monitored? Primarily, the time of project realization is monitored, then the costs that occur during project realization and resources usage. The information collected is to be sent to the competent authorities on a daily, weekly, monthly basis so that they can be instructed, if necessary, on how to deal with problematic situations (Maley, 2008; Kerzner, 2009). The reports used in the project implementation are project cost report, project status reports, project resource consumption reports, project critical activity reports and others. Project implementation problems are caused by lack of resources. Therefore, it is necessary to inform those responsible for specific activities and to ensure timely response so that no time is wasted and additional costs are created on the project.

When monitoring the project schedule, the bank keeps track of the status of the project. The relationship between the time spent and the planned time is checked, as well as the percentage of activities completed. Project managers daily report directors who, based on the information obtained, take further steps in project management. Monitoring the spending of the project is very important because it is possible to notice deviations from the planned financial resources intended for spending in the current period in order to complete the project. This information is obtained from the accounting department.

The above parameters are the best indicators of the progress of the project realization (Maley, 2008).
How is decision making obtained in a bank? Reports are sent monthly to the executive committee, which later considers how the project implementation progresses. If there are any major problems, the Executive Board is notified, and they are asked for solutions, while if the project team has a solution, the Executive Board must be notified to agree on the solutions found.

\subsection{Project closer}

The project closure is necessary to phase of project's result acceptance. The project closer report contains:

-a detailed list of tasks that was planned to be performed,

- confirmation that whether all eligibility criteria are met (or not)

- unforeseen risks and activities

- approval to close the project

- documentation containing agreements with suppliers, what resources were needed during project implementation and information to stakeholders

The project closure report is prepared by the project manager for the project sponsor or, in the case of a bank, to the executive board. At the end of the project, the document contain lessons learned (Maley, 2008).

\section{CONCLUSION}

The development of a bank's products is crucial to its business operations. E-banking projects bring profits to the bank. Technology development is progressing, so that faster and easier ways to reach the necessary resources are being used. Banks need to create new projects and turn their attention to innovative products and technology ready to use.

The paper deals with the question if the banking sector needs project management, skilled project managers and project management system. Through practical examples, the paper was focused only on the most important project management elements. The results show that new product and services development projects have to at first add business value to the bank, reach new clients and the profit, which makes project initiation phase very important. In the 
planning phase, timing, deadlines and resource plan are crucial, while the execution phase emphasizes change management, resource management and coordination of the project teams and other departments in the bank. Project monitoring and reporting are extremely important for decision making, especially due to complex organizational structure and internal procedures.

Innovations are inevitable in the banking sector, and project management can bring new ideas to life.

\section{REFERENCES}

Banfield, R., \& Ericsson, M. (2017). Product leadership. 1005 Gravenstein Highway North, Sebastopol, CA 95472: O'Reily Media Inc.

Barkley, T. B. (2018). Project management in new product development. Inc. New York: McGraw-Hill Companies.

Đorđević, B. (2006). Inovativni marketing $u$ bankama: od invencije do komercijalizacije. Beograd: Udruženje banaka Srbije.

Gareis, R. (2005). Happy projects. Wien: Manz Verlag.

Kerzner, H. (2009). Project management: A systems approach to planning, scheduling and controlling. New Jersey: John Wiley \& Sons.

Knežević, I., Todorović, M., \& Obradović, V. (2018). Upravljanje projektima kancelarija za upravljanje projektima u funkciji korporativnog upravljanja u centralnim bankama. Vojno delo, 70(4), 414-431.

Lichtarski, M. (2018). Project*drriven heterarchy: an Empirical study on project teams' learning abilities and creativity.
European Project Management Journal, 8(1), 10-16.

Lock, D. (2007). Project management. Hampshire, England.

Lučić, L. (2007). Kanali distribucije proizvoda i usluga u bankarstvu: filijale i/ili internet. Beograd: Bankarstvo.

Maley, C. (2008). Project management concept, methods and Techniques. CRC Press, Taylor \& Francis Group.

Obradović, V., Montenegro, A., \& Bjelica, D. (2018). Digital era and project manager's competencies. European Project Management Journal, 8(1).

Sanader, D. (2014). Mobilno bankarstvo: novi trend $u$ savremenom bankarskom sektoru. Beograd: Udruženje banaka Srbije.

Toljaga-Nikolić, D., Obradović, V., \& Mihić, M. (2011). Certification of Project Managers Based on IPMA and PMI Models Through Conforming to ISO 17024:2003. Management, 45-53.

Todorović, M., \& Obradović, V. (2018). Sustainability in project management: a project manager's perspective. In I. Ljumović, \& A. Éltető (Eds.), Sustainable growthand development in small open economies (p. 88). Institute of World Economics, Centre for Economic and Regional Studies of the Hungarian Academy of Sciences.

Trott, P. (2005). Innovation Management and New Product Development. Harlow, England: University of Portsmouth Business School.

Vrečko, I., Barilović, Z., \& Božičev, M. (2015). The role of IT departments in the enhancement of banks project management. Informatol, 48, 125. 